\title{
DAMPAK PANDEMI COVID-19 TERHADAP LAJU EKONOMI INDONESIA 2020 DAN ALTERNATIF SOLUSINYA
}

\author{
Dian Eka Aprilia Ningsih 1 \\ 1)Institut Agama Islam Negeri Ponorogo \\ 1) apriliadian964@gmail.com
}

\begin{abstract}
Abstrak. Latar belakang penelitian ini adalah adanya Pandemi Covid-19 yang menyebabkan runtuhnya seluruh sektor terlebih sektor perekonomian dan sektor kesehatan serta adanya kebutuhan ekonomi yang harus dipenuhi. Tujuan penulis adalah untuk menggali informasi dampak Pandemi Covid-19 serta alternatif solusinya dengan memanfaatkan media online di dalam pelaksanaannya. Metode penelitian ini menggunakan pendekatan kuantitatif dan jenis penelitian deskriptif. Hasil penelitian menyatakan bahwa untuk pencegahan resesi disarankan tetap produktif melalui digital marketing dan memakai produk dalam negeri agar investasi negara bertambah, pengangguran berkurang, dan tingkat resiko jumlah penambahan kasus Covid-19 juga berkurang.
\end{abstract}

Kata Kunci: Pandemi Covid-19; perekonomian; resesi; investasi.

\begin{abstract}
The background of this research of Covid-19 Pandemic which caused the collapse of all sectors, especially the economic sector and the health sector as well as the economic needs that must be met. The author's goal is to explore information on the impact of the Covid-19 Pandemic and alternative solution by utilizing online media in its implementation. This research method uses a quantitative approach and descriptive research type. The results of the study stated that for recession prevention, it is advisable to remain productive through digital marketing and use domestic products so that state investment increases, unemployment decreases, and the level of risk for the number of additional Covid-19 cases is also reduced.
\end{abstract}

Keywords: Covid-19; economy; recession; investation.

\section{PENDAHULUAN}

World Health Organization (WHO) menjelaskan bahwa Coronavirus (Cov) adalah virus yang menginfeksi sistem pernafasan. Infeksi virus ini disebut Covid-19. Virus Corona menyebabkan penyakit flu biasa sampai penyakit yang lebih patah seperti Sindrom Pernafasan Timur Tengah (MERS-CoV) dan Sindrom Pernafasan Akut Parah (SARS-CoV). Virus Corona adalah zoonatic yang artinya ditularkan antara hewan dan manusia. Berdasarkan Kementerian Kesehatan Indonesia, perkembangan kasus Covid-19 di Wuhan berawal pada tanggal 30 Desember 2019 dimana Wuhan Municipal Health Committee mengeluarkan pernyataan "urgent notice on the treatment of pneumonia of unknown cause". Penyebaran Covid-19 sangat cepat bahkan sampai ke lintas negara. Sampai saat ini erdapat 


\section{AL-IOTISHOD \\ Jurnal Ehonomi Suariah \\ Institut Agama Islam Sunan Kalijogo Malang \\ P-ISSN 2715-7725 E-ISSN 2721-9496 \\ Volume 3 Nomor 1 Juni 2021}

188 negara yang mengkonfirmasi terkena Covid-19. Penyebaran Covid-19 yang telah meluas ke berbagai belahan dunia membawa dampak pada perekonomian Indonesia baik dari sisi perdaganga, investasi, dan pariwisata.

Namun demikian, Covid-19 tidak hanya memberikan dampak negatif tetapi juga memberikan dampak positif bagi Indonesia. Peluang memeperkuat ekonomi dalam negeri juga dapat terlaksana karena pemerintah akan lebih memprioritaskan dan memeperkuat daya beli dalam negeri daripada menarik keuntungan dari luar negeri. Kondisi ini juga dapat dimanfaatkan sebagai koreksi agar investasi bisa stabil meskipun perekonomian global sedang terguncang.

Ekonomi merupakan salah satu faktor penting dalam kehidupan manusia. Dapat dipastikan manusia memerlukan ekonomi dalam kehidupan sehari-harinya. Keberadaan ekonomi dapat memberikan kesempatan bagi manusia untuk memenuhi kebutuhan hidupnya. Pentingnya ekonomi dalam kehidupan manusia tersebut menuntut negara untuk mengatur kebijakan tentang perekonomian dan menjamin perekonomian warga negara khususnya di Indonesia yang memproklamirkan diri sebagai negara kesejahteraan (welfare staat). Maka dari itu kestabilan perekonomian dalam negeri harus tetap dijaga demi kesejahteraan bersama. Melihat kondisi sekarang akibat adanya Pandemi Covid-19 yang membuat perekonomian Indonesia menurun maka resesi tidak bisa dikatakan jauh dari Indonesia. Dapat disimpulkan bahwa semua warga negara Indonesia dituntut bisa produktif dan tetap bisa menjaga kestabilan perekonomian Indonesia meskipun dalam kondisi yang masih belum stabil. ${ }^{1}$

Latar belakang penulis mengambil penelitian ini adalah karena melihat situasi yang sekarang dialami oleh bangsa Indonesia karena adanya Pandemi Covid-19 yang menyebabkan semua sektor menurun terlebih perekonomian Indonesia menurun bahkan bisa dikatakan hampir mengalami resesi. Penulis bertujuan untuk member saran kepada para pembaca bagaimana agar tetap bisa produktif dan ikut serta menjaga kestabilan ekonomi Indonesia pada situasi seperti sekarang ini.

${ }^{1}$ Silpa Hanoatubun. Dampak Covid-19 Terhadap Perekonomian Indonesia. (Jurnal of Education, Psychology and Counseling, 2020), h. 1 


\section{AL-IOTISHOD \\ Jurnal Ehonomi Suariah \\ Institut Agama Islam Sunan Kalijogo Malang \\ P-ISSN 2715-7725 E-ISSN 2721-9496 \\ Volume 3 Nomor 1 Juni 2021}

\section{METODE PENELITIAN}

Penelitian ini menggunakan pendekatan kuantitatif dan jenis penelitian deskriptif. Menurut Nazir (1988: 63) dalam buku Contoh Metode Penelitian, penelitian deskriptif adalah suatu metode dalam meneliti status sekelompok manusia, suatu objek, suatu set kondisi, suatu sistem pemikiran ataupun suatu kelas peristiwa pada masa sekarang. Tujuan dari penelitian deskriptif ini adalah untuk membuat deskripsi, gambaran, atau lukisan secara sistematis, factual dan akurat mengenai fakta-fakta, sifat-sifat serta hubungan antar fenomena yang diselidiki. Penelitian ini memaparkan alternatif solusi dengan tinjauan pengaruh penggunaan produk dalam negeri terhadap perekonomian Indonesia akibat Pandemi Covid-19.

Subjek penelitian ini adalah Mahasiswi IAIN Ponorogo semester 7 yang berpenghasilan kurang lebih 10 juta dalam sebulan meskipun diterapkan sistem Work From Home (WFH) yang menjadi salah satu stockist PT. Natural Nusantara. Sampel penelitian sejumlah 50 responden dari 256 orang yang merupakan mitra resmi PT. Natural Nusantara Stockist AE 3306 dengan rincian 141 distributor, 100 manajer, 13 master inti, 1 stockist, dan 2 emerald manajer. Teknik pengumpulan data melalui observasi, wawancara, pemberian kuisioner, dan turut serta berpartisipasi dalam salah satu program acara. Penulis menggunakan salah satu aplikasi dari NASA yaitu weblanding NASA sebagai salah satu sumber penulisan artikel. Penulis tidak menyertakan reseller NASA sebagai responden sebab beberapa hal yang harus dipertimbangkan. Metode pengambilan sampel menggunakan simple random sampling dalam pengumpulan data responden. Penelitian ini dilakukan sejak tanggal 10 September 2020 sampai tanggal 21 September 2020.

\section{PEMBAHASAN}

\section{Sekilas Tentang Coronavirus Desease 2019 (COVID-19)}

Coronavirus Disease 2019 (COVID-19) merupakan virus yang disebabkan SARS-COV2 yang termasuk virus keluarga besar yang menyebabkan penyakit menular dan sering disebut dengan Virus Corona. Virus ini ditemukan pertama kali di Wuhan, Tiongkok pada Desember 2019 lalu. Penyebaran Covid-19 terjadi sangat cepat dan meluas karena dapat menular melalui kontak manusia ke manusia.

Virus SARS-COV2 merupakan Coronavirus jenis baru yang menyebabkan epidemi, dilaporkan pertama kali di Wuhan, Tiongkok pada akhir tahun 2019. Pada tanggal 11 


\section{AL-IOTISHOD \\ Jurnal Ehonomi Suariah \\ Institut Agama Islam Sunan Kalijogo Malang \\ P-ISSN 2715-7725 E-ISSN 2721-9496 \\ Volume 3 Nomor 1 Juni 2021}

Februari 2020, World Health Organization (WHO) memberi nama virus tersebut Corona Virus Disease (COVID-19). ${ }^{2}$

Pada manusia biasanya menyebabkan penyakit infeksi saluran pernafasan, mulai flu biasa hingga penyakit yang serius seperti Middle East Respiratory Syndrome (MERS) dan Sindrom Pernafasan Akut Berat / Severe Acute Respiratory (SARS) (infeksiimerging.kemkes 2020). Gejala umum yang dialami berupa demam kurang lebih 380C, batuk kering, dan sesak nafas. Ada beberapa gejala lain yang juga bisa muncul pada infeksi Covid-19 meskipun lebih jarang, yaitu diare, sakit kepala, konjugtivitis, hilangnya kemampuan mengecap rasa atau mencium bau, dan ruam di kulit. Gejala-gejala Covid-19 ini umumnya muncul dalam 2 hari hingga 2 minggu pasca penderita terpapar virus Corona. Sebagian pasien yang terinfeksi virus Corona bisa mengalami penurunan oksigen tanpa adanya gejala apapun. Kondisi ini disebut happy hypoxia. Virus ini dapat menyerang siapa saja, seperti lansia (golongan lanjut usia), orang dewasa, anak-anak, dan bayi, termasuk ibu hamil dan ibu menyusui. Karena mudah menular, virus Corona juga beresiko tinggi menginfeksi para tenaga medis yang merawat pasien Covid-19. Oleh karena itu, para tenaga medis dan orang-orang yang memiliki kontak dengan pasien Covid-19 perlu menggunakan Alat Pelindung Diri (APD).

Hingga saat ini, data persebaran Covid-19 masih berada pada angka yang tinggi yakni kurang lebih mencapai 215 negara yang terserang covid dan Indonesia berada pada urutan ke 23 dengan total kasus 244.676 jiwa, dengan rincian kasus baru (1 hari) sejumlah 3.989 jiwa, dan total meninggal sekitar 3,90\% atau 9.553 jiwa, dengan rincian meninggal baru (1 hari) 105 jiwa. Prosentase kesembuhan mencapai 72,47\% atau sekitar 177.327 jiwa dengan rincian sembuh baru (1 hari) sejumlah 2.977 jiwa dan yang masih sakit atau menjalani isolasi sejumlah 57.796 jiwa (andrafarm, 2020).

\section{Dampak Pandemi Covid-19 Terhadap Indonesia}

Pandemi Covid-19 yang meresahkan semua orang juga berdampak serius terhadap hampir seluruh sektor terlebih sektor kesehatan dan sektor ekonomi. Pembatasan aktivitas masyarakat berpengaruh terhadap aktivitas bisnis yang kemudian berimbas pada perekonomian. Resesi ekonomi telah dilaporkan terjadi di sejumlah negara. Pada 1 September 2020, Presiden Joko Widodo mengatakan jika pada kuartal III 2020 pertumbuhan

${ }^{2}$ Made Mudawarsa Febriyanta. Sekilas Pandang Mengenai Virus Baru, Covid-19. (Artikel DJKN, 2020) 


\section{AL-1QTISHOD \\ Jurnal Ehonomi Suariah}

Institut Agama Islam Sunan Kalijogo Malang

P-ISSN 2715-7725 E-ISSN 2721-9496

Volume 3 Nomor 1 Juni 2021

ekonomi Indonesia kembali minus, maka kita akan mengalami resesi. Beliau berharap, pertumbuhan ekonomi Indonesia bangkit pada kuartal III 2020 (Mela Arnani, 2020).

Berikut beberapa dampak yang dialami Indonesia akibat adanya Pandemi Covid-19:

1. Angka kematian meningkat drastis

Menurut data Lapor Covid-19, per tanggal 26 Juni 2020 ada selisih 47 antara temuan positif (2.730) dengan data pemerintah (2.683). kematian terduga Covid yang tak dibuka pemerintah ditemukan sebesar 7.107 jiwa. Dengan besarnya angka ini maka Indonesia menempati peringkat ketiga negara dengan angka kematian tertinggi di Asia setelah India dengan 18.225 kematian dan Iran 11.106 kematian. Angka kematian yang mengalami peningkatan drastis sejak adanya Pandemi Covid-19 ini cukup meresahkan semua orang dan berdampak pada sektor perekonomian dikarenakan banyaknya anggaran dana yang dikeluarkan pemerintah untuk keperluan kesehatan seperti penyediaan rumah sakit khusus penderita Covid-19, pembelanjaan obat-obatan dan media alat penanganan Covid-19 serta penambahan tenaga kerja medis.

2. Pengangguran meningkat

Pengangguran merupakan hal yang akan selalu muncul di dalam perekonomian, dimana saat pengeluaran agregatnya lebih rendah dibandingkan dengan kemampuan faktorfaktor produksi yang telah tersedia di dalam perekonomian untuk dapat menghasilkan barang-barang dan juga jasa (Prasaja, 2013).

Salah satu alasan pengangguran selalu muncul di dalam perekonomian adalah pencarian kerja. Pencarian kerja (job search) adalah suatu proses seseorang untuk mencocokan pekerja dengan pekerjaan yang sesuai dengan bakat dan juga keterampilan sesuai yang dimiliki oleh mereka. Namun, jika semua pekerja dan pekerjaan tidak ada bedanya, maka tidak menutuo kemungkinan bagi para pekerja bahwa mereka cocok dengan pekerjaan apa saja, akan tetapi pada kenyataannya bakat dan juga kemampuan seseorang itu berbeda-beda (Mankiw dkk, 2013).

Pandemi Covid-19 membawa angka pengangguran di Indonesia semakin melejit. Badan Perencanaan Pembangunan Nasional (Bappenas) melaporkan, jumlah pengangguran di Indonesia beresiko akan meningkat akibat dampak Pandemi Covid-19. Menteri Perencanaan Pembangunan Nasional (PPN) / Kepala Bappenas, Suharso Monoarfa menjelaskan tingkat pengangguran terbuka diproyeksi akan meningkat 4 juta hingga 5,5 juta di tahun 2020 . 
Mengenai tingkat pengangguran terbuka itu antara 7,7\% sampai 9,1 \% di 2021. Jika itu terus terjadi dikhawatirkan sampai 2021 pengangguran sampai 10,7 juta hingga 12,7 juta.

Menurut Nanga dan Muana dalam Zarkasi (2014), menyebutkan adanya dampak dari pengangguran, salah satunya terhadap sektor perkonomian. Tingkat pengagguran yang relatif tinggi menyebabkan sulitnya masyarakat untuk mencapai tujuan tersebut yang dapat menyebabkan akibat buruk seperti :

a) Pengangguran menyebabkan seseorang kehilangan mata pencaharian dan pendapatannya.

Salah satu dampak Covid-19 adalah banyaknya ASN yang tidak produktif selama penerapan sistem Work From Home (WFH) terpaksa diberhentikan.

b) Pengangguran dapat menimbulkan akibat buruk pada sektor pariwisata. Penutupan berbagai pariwisata saat lockdown berlangsung dan pembatasan turis asing yang masuk ke Indonesia ketika penerapan new normal dapat mengurangi pendapatan negara sehingga jelas berpengaruh terhadap perekonomian Indonesia.

\section{Potensi Pemasaran Online}

Selama Pandemi Covid-19 banyak sistem aturan baru yang dikeluarkan pemerintah guna memutus rantai persebaran Covid-19. Anjuran untuk \#dirumahaja dan Penerapan Pembatsan Berskala Besar (PSBB) mulai dari lockdown, Work From Home (WFH), hingga school from home membuat masyarakat lebih banyak menghabiskan waktu di rumah. Karena itu, akses penggunaan internet termasuk media sosial semakin meningkat. Hal ini merupakan kesempatan bagi para pengusaha baik pengusaha berskala besar maupun pengusaha berskala kecil dan menengah (UKM).

Di tengah terjadi pandemi global ini, penerapan digital marketing atau strategi pemasaran online sudah harus ditingkatkan, diberdayakan dan dikembangkan oleh para pembisnis. Digital marketing menurut Urban (2004:2) adalah menggunakan internet dan teknologi informasi untuk memeprluas dan meningkatkan fungsi marketing tradisional. ${ }^{3}$ Definisi ini berkonsentrasi pada seluruh marketing tradisional. Kita juga dapat menyatakan bahwa pendapat seperti interactive marketing, one-to-one marketing dan e-marketing erat kaitannya dengan digital marketing.

${ }^{3}$ https://www.justaris.com/pengertian-digital-marketing-menurut-para-ahli-strategi-danperkembangannya-diindonesia/\#: : :text=Digital\%20marketing\%20menurut\%20Coviello\%2C\%20Milley,dan\%20kons umen\%20yang\%20telah\%20teridentifikasi. (diakses tanggal 22 Setember 2020) 


\section{AL-IOTISHOD \\ Jurnal Ehonomi Suariah \\ Institut Agama Islam Sunan Kalijogo Malang \\ P-ISSN 2715-7725 E-ISSN 2721-9496 \\ Volume 3 Nomor 1 Juni 2021}

Berikut langkah sederhana strategi digital marketing bagi pemula:

1. Digital Assets Development, yaitu menyipkan identitas digital sebuah bisnis. Aktivitas yang dilakukan antara lain membangun website dan menyiapkan akun sosial media seperti Facebook, WhattsApp, Instagram, YouTube, dll.

2. Meningkatkan kunjungan website, yaitu dengan melakukan beberapa cara seperti optimasi SEO (Search Engine Optimazion), pemasangan iklan CPC melalui Google Adsense,dll.

3. Optimasi akun sosial media, yaitu mengupayakan peningkatan interaksi dengan para pengguna sosial media dengan cara menyiapkan dan mempublikasikan konten yang menarik. Selain itu, optimalisasi dengan cara beriklan di sosial media juga patut untuk dipertimbangkan.

4. Email Marketing Activities. Email ini sebagai alat komunikasi digital yang dikenal kuno ini nyatanya masih memiliki potensi peningkatan sales berbuah bisnis. Tidak dapat dipungkiri bahwa semua pengguna smartphone diwajibkan untuk memiliki akun email untuk bisa memanfaatkan fitur smartphone secara maksimal. Kondisi ini merupakan potensi yang sangat bagus jika dimanfaatkan dengan baik.

5. Broadcast message adalah bagian dari digital marketing yang masih bisa kita jumpai. Tak jarang kita masih mendapatkan broadcast message seperti pesan singkat (SMS), WhatsApp, hingga Social Media Direct Message. Meskipun rentan mengalami pemblokiran akun, nyatanya broadcast message masih memiliki conversation rate yang cukup baik.

Selain kelima strategi diatas, ada banyak lagi strategi digital marketing yang masih sangat potensial untuk dilakukan. Mengingat strategi digital marketing merupakan bagian dari pekerjaan tim kreatif yang cakupannya sangat luas demi meningkatkan interaksi bisnis dengan calon customer.

\section{Siklus Bisnis}

Siklus bisnis (business cycle) adalah keadaan yang menunjukkan fluktuasi ekonomi suatu negara yang tercermin pada tingkat PDB riil suatu negara pada satu periode tertentu. Menurut Samuelson \& Nordhaus (2004) siklus bisnis adalah fluktuasi ekonomi pada total output nasional, pendapatan, dan ketenagakerjaan, biasanya berlangsung selama periode 2 
hingga 10 tahun, yang ditandai oleh kotraksi atau ekspansi yang tersebar luas pada kebanyakan sektor ekonomi. Dalam siklus bisnis (business cycle).

Terdapat empat fase siklus bisnis dalam aktivitasnya, yaitu:

1. Ekspansi yaitu dimana suatu negara mulai bangkit dari keterputukan.

2. Peak, yaitu suatu negara mencapai puncak-puncaknya.

3. Resesi, yaitu negara mengalami penurunan yang sangat banyak. Lanjutan dari resesi yaitu depresi, dimana nilai mata uang disuatu negara tidak ada artinya.

4. Through, yaitu suatu negara pada posisi dasar. ${ }^{4}$

Saat ini Indonesia hampir dihadapkan dengan resesi, dimana negara mengalami penurunan yang sangat banyak dikarenakan Pandemi Covid-19 yang hingga kini masih ada. Maka dari itu kita dituntut untuk tetap produktif selama Pandemi Covid-19 berlangsung dan turut serta menjaga kestabilan perekonomian negara guna menghindari resesi. Berdasarkan hasil penelitian, salah satu aktivitas atau bisnis yang cocok untuk kondisi tersebut adalah digital marketing. Selain memberi dampak baik bagi pembisnisnya, digital marketing juga memeberi dampak positif bagi pekerja lainnya seperti programmer dan kurir.

\section{HASIL DAN PEMBAHASAN}

Salah satu cara memperkuat perekonomian rakyat adalah dengan memakai produk dalam negeri. Berikut manfaat penggunaan produk dalam negeri:

1. Meningkatkan pendapatan negara (devisa).

Pendapatan negara kita pastinya akan meningkat apabila kita telah melakukan ekspor atau penjualan ke luar negeri. Maka dari itu, uang yang kita dapat dalam bentuk dollar otomatis akan kita tukarkan ke bank dan secara tidak langsung menambah cadangan devisa bagi negara ini.

2. Memeperluas lapangan pekerjaan

Dampak nyata dan sangat menguntungkan berikutnya adalah lapangan pekerjaan yang semakin bertambah. Karena jika penjualan produk asli Indonesia meningkat akan memperbanyak jumlah produksi yang mana pastinya akan membutuhkan tenaga kerja yang lebih banyak lagi.

3. Meningkatkan kesejahteraan masyarakat

${ }^{4}$ http://repository.umy.ac.id/bitstream/handle/123456789/16231/bab\%202.pdf? sequence $=6$ \&isAllowed=y\#: : :text=Menurut\%20Samuelson\%20\%26\%20Nordhaus\%20(2004),luas\%20pada \%20kebanyakan\%20sektor\%20ekonomi. (diakses tanggal 21 September 2020) 


\section{Institut Agama Islam Sunan Kalijogo Malang}

Kesejahteraan masyarakat otomatis akan meningkat apabila semakin banyak masyarakat yang memiliki pekerjaan. Angka kemiskinan di negara ini juga otomatis akan menurun apabila kita selalu menggunakan produk asli Indonesia.

4. Meningkatkan kualitas produksi

Apabila suatu industri lokal berkembang tentunya mereka akan meningkatkan kualitas dari produk mereka, biasanya para produsen akan berfikir ulang. Jika penjualan mereka sudah baik maka tahap selanjutnya yaitu peningkatan kualitas produk mereka. Hal ini biasanya mereka lakukan untuk bersaing dengan produk luar yang katanya jauh lebih baik dari produk lokal. Untuk itu mereka akan memproduksi dengan kualitas yang lebih baik lagi agar bisa bersaing dan bisa masuk ke pasar Internasional. ${ }^{5}$

Salah satu produk dalam negeri yang dapat kita jalankan sesuai prosedur pemerintah untuk tetap \#dirumahaja yang penulis gunakan sebagai objek penelitian adalah produk dari PT. Natural Nusantara (NASA). PT. Natural Nusantara (NASA) adalah perusahaan asli Indonesia karya anak bangsa yang bergerak dalam bidang distribusi produk agrokompleks berbasis organik, kesehatan, kosmetik \& kecantikan, perawatan tubuh, dan home care berbasis herbal alami serta inovasi teknologi. Perusahaan ini berdiri sejak 1 Oktober 2002 di Yogyakarta. ${ }^{6}$

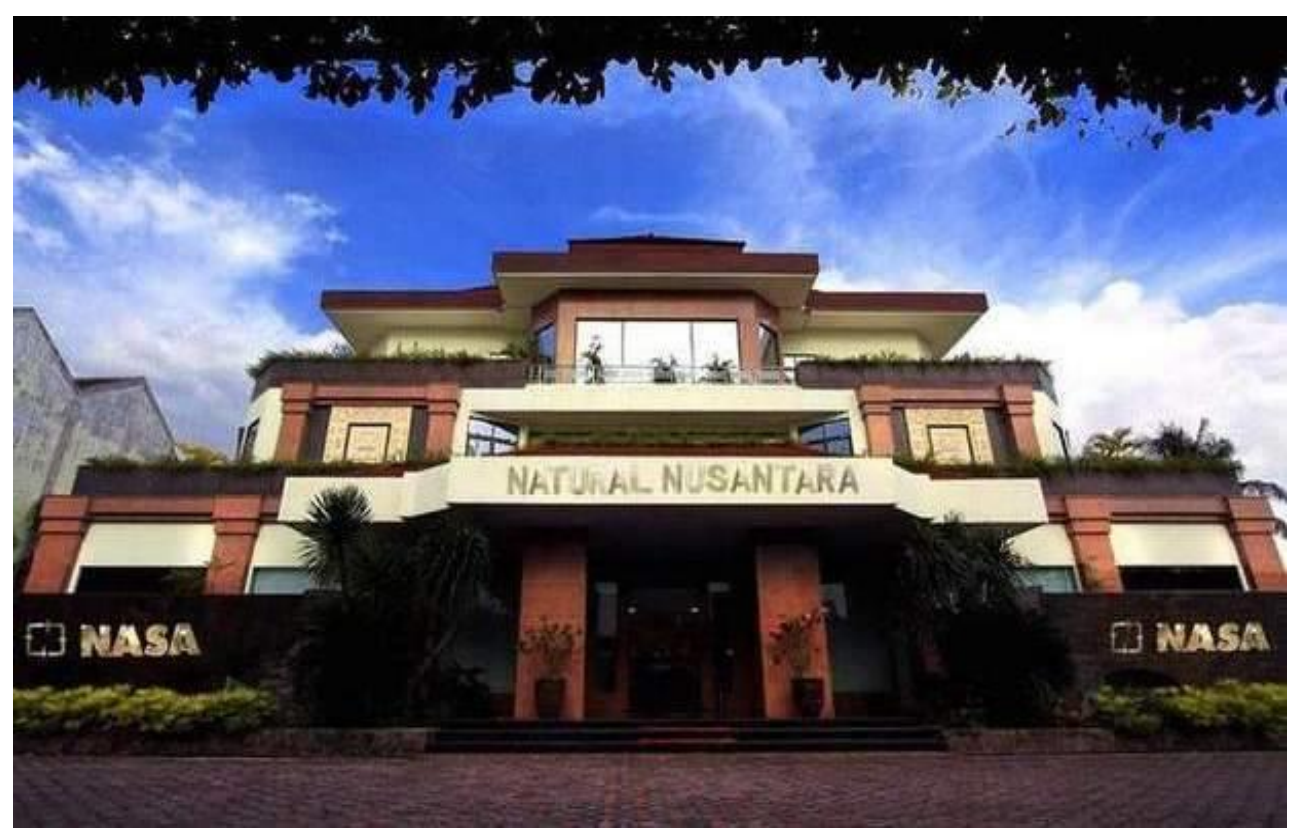

${ }^{5}$ Syahrituah Siregar. Pentingnya Memakai Produk dalam Negeri. (Banjarmasin,2011)

${ }^{6}$ https://adinmisbahwalida.weblandingnasa.com/ (diakses tanggal 23 September 2020) 


\section{Gambar 1.1}

Kantor pusat PT. Natural Nusantara. Jl. Ring Road Barat no 72 Salakan, Trihanggo, Gamping, Sleman, Yogyakarta.

Berikut prinsip kerja PT. Natural Nusantara yang dilansir dari buku Kode Etik dan Peraturan Perusahaan PT. Natural Nusantara (NASA):

1. Usaha didasarkan pada hati nurani yang jujur.

2. Selalu berfikir positif, mandiri, dan bertanggung jawab dalam menjalankan bisnis NASA.

3. Melayani orang lain dengan rendah hati dan penuh kasih.

4. Komitmen tinggi meskipun menghadapi kegagalan.

5. Pengembangan jaringan yang aktif dan peningkatan kuantitas pelanggan harus seimbang dan selaras sehimgga tercipta jaringan pemasaran yang kuat.

6. Kepuasan pelanggan (user dan end user) sebagai prioritas utama. ${ }^{7}$

Menurut buku Marketing Plan PT. Natural Nusantara, langkah mengembangkan bisnis NASA adalah sebagai berikut:

1. Memepelajari, mengenalkan, dan menjelaskan peluang bisnis dan produk NASA pada orang lain.

2. Persiapan pertemuan minimal mengadakan home sharing.

3. Sponsorisasi atau memeperkenalkan bisnis dan produk saat pertemuan.

4. Tindak lanjut setelah pertemuan. ${ }^{8}$

Subjek penelitian kali ini adalah mahasiswi IAIN Ponorogo semester 7 yang telah memiliki penghasilan sendiri sekitar 10 juta per bulan yang bergabung di salah satu bisnis dari PT. Natural Nusantara sebagai Stockist. Beliau bernama Azzahro Sofia Nabila, mahasiswi IAIN Ponorogo prodi PAI yang telah bergabung menjadi anggota resmi NASA sejak semester 1 atau tepatnya pada tahun 2017. Beliau menekuni bisnis ini hingga akhirnya bisa menjadi stockist pada Maret 2020 lalu. Perjuangan beliau juga tidak mudah dalam mencapai posisi itu. Banyak rintangan yang harus beliau hadapi hingga akhirnya bisa menjadi satu-satunya

7 PT. Natural Nusantara. Kode Etik \& Peraturan Perusahaan PT. Natural Nusantara, (Yogyakarta:PT. Natural Nusantara,2019) h. 1

${ }^{8}$ PT. Natural Nusantara. Marketing Plan PT. Natural Nusantara. (Yogyakarta:PT. Natural Nusantara, 2019), h. 13 


\section{AL-IOTISHOD}

Jurnal Ehonomi Suariah

\section{Institut Agama Islam Sunan Kalijogo Malang}

P-ISSN 2715-7725 E-ISSN 2721-9496

Volume 3 Nomor 1 Juni 2021

mahasiswa/i IAIN Ponorogo yang sudah menjadi stockist. Meskipun sedang diterapkan sistem Work From Home (WFH) namun beliau tidak merasa kehilangan pekerjaan atau usahanya dikarenakan bisnis NASA bisa dilakukan di rumah dengan menggunakan digital marketing dan marketing plan yang matang. Berbagai pendidikan NASA di berbagai daerah ia ikuti dengan maksimal dan selalu take action semua ilmu yang didapat.

Berikut beberapa foto Nabila saat menghadiri Pendidikan NASA dan penerimaan penghargaan sebagai Stockist.

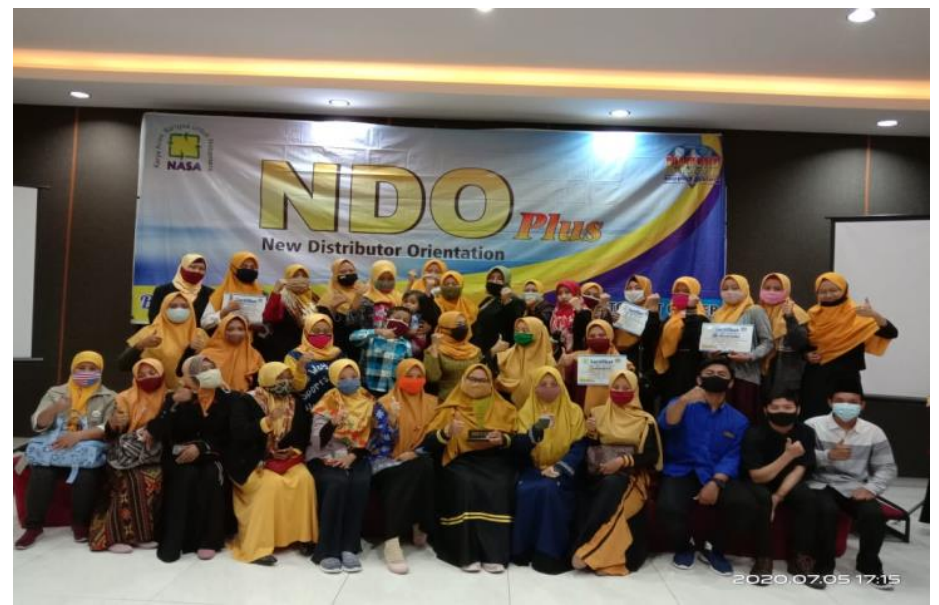

Gambar 1.2

Foto Nabila saat menghadiri salah satu Pendidikan NASA di Graha Mangga Madiun

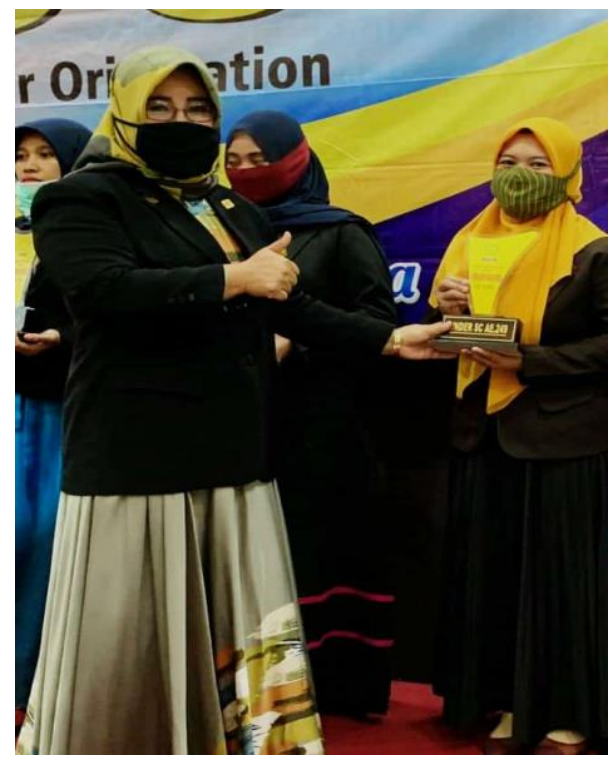

Gambar 1.3

Foto Nabila saat menerima penghargaan sebagai Stockist 
Berikut 50 data responden dari 256 anggota

\begin{tabular}{|c|c|c|}
\hline NO & NAMA & PERINGKAT \\
\hline 1. & Siti Uswatun Hasanah & Emerald Manajer \\
\hline 2. & Azzahro Sofia Nabila & Gold Manajer \\
\hline 3. & Nuzulul Indah Pertiwi & Silver Manajer \\
\hline 4. & Denis Aryani & Manajer \\
\hline 5. & Adin Misbah Walida & Manajer \\
\hline 6. & Nunung Khofifah & Manajer \\
\hline 7. & Binti Lathifathul Aini & Manajer \\
\hline 8. & Hanifah Fauziyah & Manajer \\
\hline 9. & Elfia Damayanti & Manajer \\
\hline 10. & Titis Awaliya & Distributor \\
\hline 11. & Tarbiyyatul Ulum & Distributor \\
\hline 12. & Dian Eka Aprilia N & Distributor \\
\hline 13. & Aprilia Putri & Distributor \\
\hline 14. & Yusuf Bayu Saputra & Distributor \\
\hline 15. & Rozab Alfan Fadhillah & Distributor \\
\hline 16. & Adib Rohmat & Distributor \\
\hline 17. & Abid & Distributor \\
\hline 18. & Alfina Krismonika & Distributor \\
\hline 19. & Sri Andayani & Distributor \\
\hline 20. & Erna Fitri Indiani & Distributor \\
\hline 21. & Yuspita Sri Rahayu & Distributor \\
\hline 22. & Siti Maria Ulfa & Distributor \\
\hline 23. & Sunik & Distributor \\
\hline 24. & Sri Partini & Distributor \\
\hline 25. & Nabila Husna Maulida & Distributor \\
\hline 26. & Fitria Umi Murofiah & Distributor \\
\hline 27. & Ery & Distributor \\
\hline 28. & Uswatun Hasanah & Distributor \\
\hline 29. & Winarsih & Distributor \\
\hline 30. & Chossita Maratu Zahra & Distributor \\
\hline 31. & Aprilia Tri Maulida & Distributor \\
\hline 32. & Dita Tri Agustina & Distributor \\
\hline 33. & Anis Rofi'ah & Distributor \\
\hline 34. & Fajria & Distributor \\
\hline 35. & Supartiyem & Distributor \\
\hline 36. & Faris Abdilla & Distributor \\
\hline 37. & Tarissa Fathin & Distributor \\
\hline 38. & Puwati Ningsih & Distributor \\
\hline 39. & Ali & Distributor \\
\hline
\end{tabular}




\begin{tabular}{|l|l|l|}
\hline 40. & Ihdi Hadi Qalbi & Distributor \\
\hline 41. & Sri Rahayu & Distributor \\
\hline 42. & Ayuk Eka Agustin & Distributor \\
\hline 43. & Siti Aminatun Fadhilah & Distributor \\
\hline 44. & Ninik Susianti & Distributor \\
\hline 45. & Aril Deva Nayla & Distributor \\
\hline 46. & Sri Wahyuni & Distributor \\
\hline 47. & Arik & Distributor \\
\hline 48. & Ma'ruf Nawawi & Distributor \\
\hline 49. & Azizah Diah Falupi & Distributor \\
\hline 50. & Hidayati Nur Istiqomah & Distributor \\
\hline
\end{tabular}

Tabel 1.1

Data 50 responden dari 256 anggota

\section{KESIMPULAN DAN SARAN}

Coronavirus Disease 2019 (COVID-19) merupakan virus yang disebabkan SARS-COV2 yang termasuk virus keluarga besar yang menyebabkan penyakit menular dan sering disebut dengan Virus Corona. Virus ini ditemukan pertama kali di Wuhan, Tiongkok pada Desember 2019 lalu. Penyebaran Covid-19 terjadi sangat cepat dan meluas karena dapat menular melalui kontak manusia ke manusia.

Pandemi Covid-19 yang masih merebak di dunia termasuk di Indonesia membuat hampir seluruh sektor terganggu aktivitasnya terlebih sektor kesehatan dan sektor ekonomi. Tingginya angka kematian dan angka pengangguran menyebabkan tingginya angka kemiskinan yang ada di Indonesia. Lonjakan anggaran negara yang berbanding terbalik dengan melemahnya rupiah membuat Indonesia hampir dihadapkan dengan resesi. Ditambah dengan aturan pemerintah yang menerapkan Pembatasan Berskala Besar (PSBB), Work From Home (WFH) dan School Home guna pemutusan rantai penyebaran Covid-19 mengharuskan semua orang mematuhi aturan untuk tetap \#dirumahaja. Salah satu dampak dari sistem tersebut adalah banyaknya ketenagakerjaan yang hilang sedangkan mereka tetap membutuhkan pekerjaan agar bisa mendapatkan penghasilan meskipun kondisi seperti ini. Berdasarkan hasil penelitian, salah satu solusinya adalah dengan menjalankan digital marketing produk dalam negeri. Karena dengan digital marketing selain menguntungkan bagi pembisnis yang menggunakan digital marketing juga bisa memeberi banyak peluang bagi tenaga kerja yang lain seperti programmer dan kurir. 


\section{AL-IOTISHOD \\ Jurnal Ehonomi Suariah \\ Institut Agama Islam Sunan Kalijogo Malang \\ P-ISSN 2715-7725 E-ISSN 2721-9496 \\ Volume 3 Nomor 1 Juni 2021}

Siklus bisnis (business cycle) adalah keadaan yang menunjukkan fluktuasi ekonomi suatu negara yang tercermin pada tingkat PDB riil suatu negara pada satu periode tertentu. Terdapat 4 fase siklus bisnis dalam aktivitasnya, salah satunya adalah resesi. Jika produk yang dipasarkan dalam digital marketing adalah produk dalam negeri maka pendapatan negara secara tidak langsung akan bertambah juga dan dapat membantu perekonomian negara sehingga resiko resesi lebih kecil. Salah satu produk dalam negeri yang diteliti oleh penulis adalah produk dari PT. Natural Nusantara yang merupakan perusahaan asli Indonesia karya anak bangsa yang bergerak dalam bidang distribusi produk agrokompleks berbasis organik, kesehatan, kosmetik \& kecantikan, perawatan tubuh, dan home care berbasis herbal alami serta inovasi teknologi. Perusahaan ini berdiri pada tanggal 1 Oktober 2002 di Yogyakarta. Bisnis ini dapat dilakukan secara offline maupun online dan telah melahirkan ratusan pembisnis luar biasa yang salah satunya dijadikan subjek penelitian oleh penulis yaitu mahasiswi IAIN Ponorogo semester 7, Azzahro Sofia Nabila yang telah memiliki penghasilan kurang lebih 10 juta per bulan meskipun Pandemi Covid-19 belum berakhir.

Penulis menyarankan agar masyarakat tetap produktif meskipun kondisi yang masih belum stabil dengan minimal menjadi pembisnis dalam digital marketing terlebih dengan produk dalam negeri guna mengurangi jumlah pengangguran dan mencegah resiko resesi. 


\section{DAFTAR PUSTAKA}

Febriyanta, Made Mudawarsa. Sekilas Pandang Mengenai Virus Baru, Covid-19. Artikel DJKN, 2020.

Hanoatubun, Silpa. Dampak Covid-19 Terhadap Perekonomian Indonesia. Jurnal of Education, Psychology and Counseling, 2020, 1.

“Tinjauan Pustaka, Pengertian Siklus Bisnis,". Home page on-line. Available from http://repository.umy.ac.id/bitstream/handle/123456789/16231/bab\%202.pdf?seq uence $=6$ \&isAllowed $=y \#: \sim:$ text $=$ Menurut $\% 20$ Samuelson $\% 20 \% 26 \% 20$ Nordhaus $\% 20$ ( 2004),luas\%20pada\%20kebanyakan\%20sektor\%20ekonomi; Internet; Accesed 21 September 2020.

https://adinmisbahwalida.weblandingnasa.com/; Accesed 23 September 2020.

“Keuntungan Menggunkan Produk Dalam Negeri," Home page on-line. Available from https://mallonlineindonesia.com/keuntungan-menggunakan-produk-dalam-negri/; Internet; Accesed 22 September 2020.

Prayitno, Aris. "Pengertian Digital Marketing Menurut Para Ahli, Strategi, dan Perkembangannya di Indonesia," Available from https://www.justaris.com/pengertian-digital-marketing-menurut-para-ahli-strategidan-perkembangannya-diindonesia/\#: :text=Digital \%20marketing\%20menurut $\% 20$ Coviello\%2C\%20Milley,d an\%20konsumen\%20yang\%20telah\%20teridentifikasi; Internet; Accesed 22 September 2020.

Nusantara, PT. Natural. "Kode Etik \& Peraturan Perusahaan PT. Natural Nusantara", Yogyakarta:PT. Natural Nusantara, 2019.

Nusantara, PT. Natural. Marketing Plan PT. Natural Nusantara. Yogyakarta:PT. Natural Nusantara, 2019.

Siregar, Syahrituah. Pentingnya Memakai Produk dalam Negeri. Banjarmasin, 2011. 